\title{
Kolokacje leksemu wojna w dziejach języka polskiego. Analiza semantyczna
}

\section{Abstrakt}

W artykule przedstawiona została łączliwość rzeczownika wojna w ujęciu diachronicznym. Zebrane $\mathrm{z}$ historycznych słowników języka polskiego kolokacje bogato ilustrują różne znaczenie leksemu jako 'konfliktu', 'walki', 'wyprawy wojennej' oraz 'służby wojskowej. Pod względem formalnym zdecydowanie przeważają połączenia z czasownikami, które w pełni odzwierciedlają dynamiczny charakter wojny i metaforyczny sposób jej obrazowania jako żywiołu ognia i burzy, poświadczony również przez połączenia z rzeczownikami. Szczególnie bogaty zbiór kolokacji dokumentuje rozpoczęcie, prowadzenie i zakończenie działań wojennych. Z kolei połączenia z przymiotnikami, oprócz opisu różnych parametrów wojny, jak czas, przestrzeń, strategia, są językowym odzwierciedleniem determinowanych przez wojnę emocji i świadectwem jej wartościowania z względnej perspektywy. Wiele połączeń wyrazowych odznacza się znaczną trwałością i w niezmienionej formie zachowało się w języku współczesnym.

Słowa kluczowe: leksem wojna, kolokacja, semantyka, językowy obraz świata.

Pod pojęciem „kolokacja” w niniejszym artykule rozumiane będzie „połączenie wyrazów, powstałe na zasadzie zgodności semantycznej i formalnej, niebędące jednak stałym związkiem wyrazowym" (Markowski 2004: 252). Tak szerokie definiowanie terminu zostało przyjęte i omówione również w toku dyskusji nad koncepcją Wielkiego słownika języka polskiego (Przybylska 2007; Rokicka 2007; Węgrzynek 2007).

Na potrzeby tego artykułu kolokacje leksemu wojna wyekscerpowane zostały ze Słownika staropolskiego, Słownika polszczyzny XVI wieku, Słownika języka polskiego Samuela Bogumiła Lindego, Słownika wileńskiego, Słownika warszawskiego, a także z Kartoteki „Stownika języka polskiego XVII i pierwszej połowy XVIII wieku”". Ponieważ pola kolokacyjne pewnych wyrazów mogą się z sobą krzyżować, a w niektórych wypadkach nawet zawierać w polu kolokacyjnym innego wyrazu, ekscerpcji poddano całe słowniki, a w przypadku Słownika polszczyzny XVI wieku tomy dotychczas wydane (hasło wojna nie zostało jeszcze opracowane). Ze względu na obfitość zebranego materiału w niniejszym artykule nie zostaną uwzględnione połączenia

${ }^{1}$ Analiza kolokacji wyekscerpowanych ze współczesnych słowników języka polskiego zostanie przedstawiona w odrębnym artykule. 
z przymiotnikiem wojenny - ‘odnoszący się do wojny, właściwy wojnie’; będą one przedmiotem odrębnego opracowania.

W okresie staropolskim rzeczownik wojna oznaczał 'wyprawę wojenną, 'walkę, bitwę, 'wojsko', 'obowiązek służby wojskowej' oraz 'daninę, którą zobowiązani byli złożyć kmiecie panu wyruszającemu na wojnę’ (SStp, t. 10: 282-283). W późniejszym okresie ostatnie znaczenie ('danina') nie będzie potwierdzane, natomiast wojną zacznie się nazywać także 'spór, kłótnię. Zebrane ze słowników połączenia wyrazowe bogato ilustrują wszystkie wymienione znaczenia.

Jako człon główny grupy nominalnej rzeczownik wojna występuje w charakterystycznych połączeniach z zaimkiem dzierżawczym nasza, niekiedy również z zaprzeczeniem nie nasza wojna, oraz z zaimkami wskazującymi: w tekstach staropolskich ona, w okresie późniejszym ta wojna. Nierzadko notowane są też połączenia z zaimkami wszytka, każda, informującymi, że nie ma takich wojen, których nie dotyczy to, co zostaje o nich powiedziane. W całym analizowanym okresie liczne są połączenia z przymiotnikami nacechowanymi emocjonalnie, co ilustrują wybrane przykłady, na przykład z SPXVI: wojna przeklęta, opłakana (w funkcji przymiotnikowej: 'godna pożałowania, nieszczęsna, żałosna'); okrutna, mizerna - 'budząca litość, godna współczucia, politowania'; nikczemna - 'zła, przynosząca szkodę, niewłaściwa’; z KSXVII: przykra, straszliwa, sprośna, uprzykrzona, nieszczęsna, zawzięta; z SLin: niezbedna - 'sprośna, plugawa, brzydka', waśliwa - 'kłótliwa, gniewliwa', sroga, straszna, okrutna; z SWar: przeklęta, ciężka. W SPXVI i źródłach dla czasów późniejszych niezmiennie występują kolokacje z przymiotnikiem krwawa, niekiedy barzo krwawa, rzadziej opływająca krwią. Słowniki z różnych okresów rejestrują także połączenie bezkrwawa wojna, podkreślające jej nietypowy, wyjątkowy charakter.

Wśród określeń o treściach aksjologicznych uwagę zwraca notowana w SPXVI i KSXVII kolokacja wojna sprawiedliwa - 'uzasadniona, słuszna', w której przymiotnik wartościujący łączy się niekiedy z wykładnikiem stopnia cechy dosyć sprawiedliwa. W tym kontekście występują również połączenia: wojna prawa - 'sprawiedliwa, prowadzona w celach obronnych' (SPXVI); słuszna, dobra (KSXVII). Godne odnotowania wydają się kolokacje z SPXVI: wojna święta, w tym z modulantem wrzkomo święta, wojna Pańska - 'nakazana przez Boga', a także szczéśliwa, ze zdaniem rozwijającym: która $z$ wola Boża będzie zaczęta; z KSXVII: wojna Chrystusowa; z SLin: wojna pobożna - 'święta, z przyczyn religijnych, o grób Pański', które odzwierciedlają powszechne w staropolskim świecie przekonanie o bezpośredniej ingerencji Boga w życie człowieka. Przeciwstawne znaczenie komunikują natomiast połączenia z SPXVI: wojna niesprawiedliwa, nieszczéśliwa, niepotrzebna, mizerna - 'niegodziwa, podła, grzeszna'; z KSXVII: wojna świętokradzka, niezbożna, niedobra, niesprawiedliwa, niesłuszna, szkodliwa.

Liczna grupa kolokacji z przymiotnikami koncentruje się wokół strategii i taktyki. SLin rejestruje połączenia wojna zaczepna (bellum offensivum) oraz przeciwstawne mu wojna odporna (bellum defensivum), podobnie: wojna następujaca i broniaca. W tym kontekście wystąpiło jeszcze jedno interesujące połączenie: wojna od nas 
i przeciwko nam czyniona. Kolokacji odnoszących się do wojny ofensywnej mamy w SLin więcej niż do defensywnej, jest tu na przykład wojna następna - 'następująca na kogo, napastna, zaczepna' oraz wojna wstępna - 'zaczepna, wtrętna'. SWar powtarza te konstrukcje i dodatkowo notuje wojnę najezdnicza — 'zaczepna, zaborcza' oraz połączenie o znaczeniu przeciwstawnym wojna odwetowa.

Odpowiednie wykorzystanie oddziałów wojskowych podczas działań wojennych komunikowały zarejestrowane w KSXVII kolokacje: wojna piesza (por. pie$s z y$ - ‘żołnierz piechoty', SPXVI, t. 24: 151) ${ }^{2}$, piechotna (por. piechota - ‘żołnierze walczący pieszo', SPXVI, t. 24: 34), konna (por. konny - 'żołnierz walczący na koniu', SPXVI, t. 10: 572) oraz wodna wojna okrętowa. SWar podaje natomiast kolokacje koncentrujące się na działaniach taktycznych: wojna partyzancka oraz podjazdowa, które ustabilizowały się $\mathrm{w}$ języku w funkcji terminów specjalistycznych z zakresu wojskowości. Z kolei z rozwojem terminologii prawniczej wiązać należy zarejestrowane w tym słowniku połączenia: wojna sukcesyjna, secesyjna, dewolucyjna (fr. devolution - 'przejście prawa do czegoś na kogo innego').

Wyekscerpowane ze słowników kolokacje z przymiotnikami koncentrują się wokół różnych parametrów; jednym $\mathrm{z}$ nich jest szeroko rozumiany charakter przebiegu wojny. W grupie tej można zauważyć połączenia informujące o dynamice i intensywności zdarzeń, na przykład z SPXVI: wojna niespodziewana, nagła, gwałtowna, ostra; SLin: wojna goraca; SWar: wojna nieugaszona - 'nienasycona, niedająca się stłumić, uspokoić, wojna zacięta. Inna grupa odnosi się do sposobu działania stron konfliktu, na przykład z SPXVI: wojna jawna, otworzysta - 'wyraźna, oczywista'; KSXVII: odkryta, widoma; SLin: otworzysta - 'otwarta, nie przez fortel'; SWar: otwarta. Przeciwstawne znaczenie komunikuje zaś pochodzące z KSXVII połączenie wojna sekretna. Na następną grupę składają się połączenia odzwierciedlające rozmiar konfliktu, na przykład z SPXVI: wojna wielka, potężna, mała; KSXVII: wojna walna (por. walny - 'powszechny, generalny, główny', SLin, t. 6: 216); SWar za słownikiem Trotza: wojna olbrzymska (przymiotnik od olbrzym). Z SPXVI pochodzi jeszcze kolokacja wojna potoczna - 'zwykła, codzienna', której można przeciwstawić połączenie z partykułą zaprzeczoną nie leda wojna, informującą o nieprzeciętności, niepospolitości, wielkim znaczeniu desygnatu wyrazu określanego. Duży rozgłos, a przede wszystkim trwałe miejsce $\mathrm{w}$ historii odzwierciedla natomiast połączenie sławna wojna (SPXVI).

Wśród kolokacji wskazujących na uczestników konfliktu połączenia z przymiotnikami są raczej nieliczne; SPXVI podaje za słownikiem Mączyńskiego wojna zbójcomorska - 'którą zbójcy morscy wiodą między sobą', a ponadto notuje: wojna pogańska, kacerska (przymiotnik od kacerz - 'ujemne w odcieniu miano przeciwnika religijnego'), chłopska (odnosząca się do powstania chłop-

${ }^{2}$ Podając znaczenie wyrazów, będę odsyłać do źródła jedynie w wypadku, gdy wyjaśnienie to zaczerpnięte zostało z innego źródła, niż pochodzi analizowana kolokacja. Taka sytuacja dotyczy połączeń wyrazowych z KSXVII, a dla XVI wieku - tych leksemów, które znajdą się w niewydanych jeszcze tomach SPXVI. 
skiego w Niemczech w XVI wieku), ludzka - 'występująca między ludźmi'; z kolei SWar notuje: wojna bracka (przymiotnik od bracki - 'należący do bractwa'). W tym kontekście rzeczownik wojna znacznie częściej łączy się z wyrażeniami przyimkowymi; typowe konstrukcje pochodzące ze SPXVI realizowały następujące schematy: wojna $z$ kim: $z$ nieprzyjacielem / $z$ nieprzyjacioły, $z$ przeciwniki, $z$ pogany, z ruskimi kniaźmi, z Turki, z kościołem, z Bogiem, z szatanem, z żadnym ' $z$ nikim', $z$ heretykami, $z$ bracia, z panna, $z$ Rusia; wojna przeciw(ko) komu podniesiona: wojny poddanych przeciw panom, wojna przeciw poganom, przeciwko cesarzowi tureckiemu, przeciwko nieprzyjacielowi, przeciw królowi, przeciwko miastu, przeciw przysięgłemu swemu panu; wojna na kogo podniesiona: na nieprzyjaciela, na katoliki; wojna miedzy kim: miedzy ludźmi i narody, miedzy dwiema stronoma albo dwiema personoma. Szeroko rozumianą sytuację stron konfliktu charakteryzuje z kolei połączenie z KSXVII: wojna nierównia (por. nierównia - 'taka, która przewyższa czyjeś siły', SPXVI, t. 18: 1).

Kolokacje z przymiotnikami komunikują niekiedy, jakich spraw dotyczy wojna, co ilustrują przykłady z SPXVI: wojna duchowna - 'dotycząca ducha w znaczeniu teologicznym', wojny ziemskie - 'dotyczące spraw ziemskich' W tym kontekście występują także połączenia z wyrażeniem przyimkowym wojna z czym: z cielesnościa nasza, z namiętnościami, z grzechem, $z$ dawnym zwyczajem.

Ważnym parametrem wojny jest jej usytuowanie w czasie i przestrzeni. Porządkowaniu chronologicznemu wojen jako zdarzeń historycznych służą połączenia z przymiotnikami, na przykład z SPXVI: wojna nowa, przyszła, przeszła; KSXVII: świeża, teraźniejsza; SLin: obecna - 'aktualna', SWar: miniona, zaprzeszła —'dawno przeszła' W omawianym kontekście rzeczownik wojna nierzadko występuje w formie liczby mnogiej, co dodatkowo kieruje uwagę na kolejny atrybut wojny, jakim jest jej cykliczność i powtarzalność. Właściwość tę konotuje większość wymienionych przymiotników, ale najwyraźniej sygnalizują ją następujące kolokacje z SPXVI i SWar: wojny częste; z SLin: wojny gęste - 'częste'; z SWar: wojna powtórna. Godne uwagi wydają się też kolokacje odzwierciedlające przekonanie, że wojny toczą się ciągle, nieprzerwanie: wojna ustawiczna / wojny ustawiczne (SPXVI i słowniki dla okresu późniejszego); w tym kontekście SLin notuje jeszcze połączenie wojny ustawienie trwaja.

Długość trwania konfliktu wydaje się szczególnie istotna w nominacji wojen, w której wykorzystywane są przymiotniki złożone, na przykład z SPXVI: wojna trzynastoletnia; SLin: wojna ośmletnia; SWar: wojna siedmioletnia, trzydziestoletnia. W pozostałych kolokacjach zebranych ze słowników informacje o czasie trwania zazwyczaj są dość ogólne, na przykład SLin: długo zabawna wojna - 'długo ciągnąca się, długo bawiąca', czyli zajmująca; SWar: wojna długa, długowieczna.

Charakterystyce temporalnej służą nadto połączenia z rzeczownikami nazywającymi jej poszczególne etapy, w SPXVI są to: początek oraz poczęcie wojny - 'rozpoczęcie się wojny', przewłoka od wojny - 'przerwa, odpoczynek, spokój, koniec wojny / wojnie, skończenie wojny, nazywane również rozjęciem wojny - 'rozstrzyg- 
nięcie wojny'; w KSXVII: początek, zaczęcie, continuowanie, przewłoka, kończenie, skończenie, dokończenie wojny, koniec wojny /wojnie, zwany też uspokojeniem wojny; w SLin i SWar: przewłok - 'przewłoka', przegrywka wojny - 'gra wstępna, wstęp do gry'; SWar: początek, odrozpoczęcie - 'wznowienie, zaczęcie od nowa', przewłoka, kres wojny. Z grupą tą wiązać należy także obecne już w SPXVI kolokacje dzień oraz czas wojny. Z kolei właściwe źródłom z różnych epok połączenia z czasownikami ruchu, w których wojna występuje jako agens, na przykład SPXVI: wojna nadchodzi; SWar: wojna idzie, występują zarówno w funkcji temporalnej, jak i lokatywnej.

Usytuowanie wojny w przestrzeni najczęściej opisywane jest przez liczne połączenia z przymiotnikami. W ogólnej charakterystyce lokatywnej na plan pierwszy zdaje się wysuwać stopień oddalenia przestrzennego działań wojennych. Informację o bliskości i przyległości obszaru objętego wojną wnoszą kolokacje z SPXVI: wojna ościenna - 'pograniczna, sąsiedzka', zaścienna - 'ościenna' oraz z KSXVII: wojna nieodległa, sąsiedzka, a także połączenie z wyrażeniem przyimkowym wojna blisko domu. Na znaczne oddalenie wskazują natomiast kolokacje z SPXVI, który za słownikiem Mączyńskiego notuje: wojna daleko i szeroko rozciagniona; z KSXVII i SLin: wojna daleka; z SWar: wojna zamorska. Z kolei połączenia: wojna wnętrzna, wewnętrzna, domowa (SPXVI), nie konkretyzując przestrzeni, opisują obszar zamknięty granicami jednego państwa, a połączenie wojna powiatowa (SPXVI) czy z wyrażeniem przyimkowym wojna w parafii (KSXVII) zawężają terytorium w sposób znaczny. Ogólną informację o geografii wojny rozgrywającej się poza granicami państwa przynoszą też konstrukcje z przymiotnikami: postronna, obca, zagraniczna (SLin). Kolokacje z przymiotnikami określającymi strony świata, jak wielka wojna północna (SWar), są zupełnie wyjątkowe. Z kolei połączenie z SPXVI wojna morska przenosi działania poza ląd, ograniczając ich zasięg do obszaru wodnego.

Konkretyzacji przestrzeni objętej działaniami wojennymi służą najczęściej przymiotniki motywowane nazwami etnicznymi, na przykład z SPXVI: wojna wałaska, turecka, węgierska, litewska; z KSXVII: wojna hiszpańska, portugalska, wojny francuskie, niderlandzkie; z SLin: wojna pruska, francuska, brandeburska, szlaska; z SWar: wojna szwedzka. Wśród tych kolokacji uwagę zwraca połączenie wojna panniemiecka (SWar), rozszerzające obszar konfliktu na wszystkie ówczesne państwa niemieckie. Mniej liczne są połączenia z przymiotnikami od nazw miejscowych, najstarsze odnotowane zostało już w SStp: wojna brodnicska (kedi gechano na brodniczsczq woynq... - 1423 rok); SPXVI podaje: wojnę moskiewska, warneńską; KSXVII: wojnę mediolańską; SLin: wojnę rzymską; SWar: wojnę wiedeńska. W grupie dawnych kolokacji opisujących geografię wojen zupełnie sporadycznie notowane są połączenia z wyrażeniami przyimkowymi, na przykład wojna w Prusiech (SPXVI).

Charakterystyce lokatywnej służą ponadto połączenia z rzeczownikami nazywającymi miejsce, w którym konflikt się rozpoczął lub trwa; SPXVI rejestruje: gniazdo wojny; SWar: teatrum wojny krwawej, teatr, teren, plac wojny - 'bojowisko, teatr wojny'. W tym polu semantycznym na uwagę zasługuje również zaczerpnięte z SPXVI 
połączenie $\mathrm{z}$ rzeczownikiem odczasownikowym przeniesienie wojny - 'zmiana miejsca działań wojennych' oraz konstrukcje z czasownikami pochodzące ze źródeł późniejszych, na przykład z SWil: rozwodzić wojne — 'rozłączać, prowadzić w różne strony'; z SWar: umiejscowić wojne — 'skupić w jednym miejscu, nie dopuścić do rozszerzenia się.

Kolejną interesującą grupę tworzą połączenia z rzeczownikami osobowymi wskazującymi inicjatora działań wojennych; SPXVI rejestruje następujące przykłady: przyczyńca wojny - 'sprawca, ten, kto coś spowodował', powód do wojny - 'inicjator, pomysłodawca, sprawca'; KSXVII: pryncypał wojny (por. pryncypat - 'początek dający sprawie jakiej, początek, głowa, przełożony’, SLin, t. 4: 492); SLin: zapalacz, wzburzyciel - 'ten, który wzburza, podburza'; SLin i SWar: sprawca wojny, podżoga wojny - przen. 'kusiciel, powód, sprawca, instygator'. Z kolei połączenia z SPXVI: pomocnik na wojne - 'sprzymierzeniec' oraz z SWar: pomocnik i forytarz do podniesienia wojny - 'pomocnik i wspólnik' odzwierciedlają koncepcję wojny realizowanej poprzez umowy i sojusze. W tym kontekście godna uwagi wydaje się jeszcze kolokacja z czasownikiem spisać się na wojnę z kim (SLin), a nadto połączenia z przymiotnikami - z SLin: wojna przymierna (przymierny przymiotnik od przymierze) oraz z SWar: wojna koalicyjna.

Następna dość licznie reprezentowana grupa połączeń z rzeczownikami nazywa źródło konfliktu; na przykład z SPXVI: poczatek - 'przyczyna, źródło', nasienie, matka wojny - 'przyczyna, warunek, coś, co jest konieczne dla istnienia czegoś innego'; SPXVI i KSXVII: sprawiedliwa przyczyna wojny; SLin: stuszny powód do wojny, podniata (ob. podnieta), podżeg (ob. podżoga — 'podnieta') wojny; SWar za za słownikiem Trotza: zasiew wojny - 'zarodek', a ponadto: nasienie wojny. W tym kontekście warte odnotowania jest również pochodzące z SLin połączenie wojne podnieść z nawodu (nawod - 'powód'). Przyczynę wojny w sposób dość ogólny wskazują niekiedy także kolokacje z przymiotnikami; nieliczne przykłady pochodzą z SPXVI: wojna przypadkowa, rozruchowa - 'powstała z rozruchów, z zamieszek' oraz połączenie wojna wrodzona, które odzwierciedla przekonanie, że wojna właściwa jest człowiekowi z przyrodzenia, jest jego naturalną cechą. Ukonkretnienie przyczyny leżącej u podłoża wojny najczęściej dokonuje się w połączeniach z wyrażeniami przyimkowymi, realizującymi schemat składniowy wojna o co, na przykład SPXVI: wojna o krzywdę, o mała rzecz, o rzeczy stuszne, o państwo, o papiestwo, o królestwo węgierskie; z SWar: wojna o cześć kobiety. Połączenia z wyrażeniami przyimkowymi służą niekiedy także do komunikowania celu wojny; ilustrujące przykłady pochodzą z SPXVI: wojna jest / ma być podnoszona dla pomszczenia kogo, dla odwetowania krzywd, dla oswobodzenia brata.

Specyfikę czasu bezpośrednio poprzedzającego rozpoczęcie wojny odzwierciedlają liczne konstrukcje złożone z czasownika i wyrażenia przyimkowego: na wojnę, ku wojnie, do wojny, na przykład z KSXVII: idzie, zbiera się na wojnę; SLin: zaciaga się, zanosi się na wojnę, ma się ku wojnie / do wojny; SWar: przyjdzie / nie przyszło do wojny, ma się ku wojnie, zachodzi na wojnę - 'idzie ku wojnie, zanosi się na wojnę', 
zbiera się na wojnę, kroi się na wojnę. SWar w tym kontekście rejestruje jeszcze połączenie z charakterystycznym dla polszczyzny potocznej wyrażeniem przyimkowym wojna na karku.

Wojna, zarówno jako wydarzenie historyczne, jak i potencjalne, staje się przedmiotem spekulacji myślowych człowieka, co potwierdzają kolokacje z rzeczownikami, na przykład z SPXVI: mniemanie wojny - 'przypuszczenie, domysł', podejrzanie wojny; SLin: pogłos wojny - 'wieść posłuch'; SWar: myśl o wojnie, pogłoski o wojnie; jak również z czasownikami, na przykład z KSXVII: wyglądać, spodziewać się wojny; SLin: upatrywać, wyglądać wojny. W tym kontekście pojawiają się także połączenia z czasownikami nazywającymi aktywność werbalną człowieka, na przykład SLin: szeptać o wojnie; SWar: przebąkiwać o wojnie - 'zdobywać się na nieśmiałe słówko'. Przekonanie o zagrożeniu wojną lub jej nieuchronności komunikują niekiedy przymiotniki, na przykład z SPXVI: wojna pewna; KSXVII: wojna gotowa. Z kolei połączenia z czasownikami wróżyć wojny czy omenować wojnę - 'przepowiadać' (SWar) przechowały relikty magicznego myślenia o wojnie, które poświadczają również kolokacje z rzeczownikami: bóg, bogini, bożek wojny, obecne w różnych źródłach, począwszy od XVI wieku.

Powtarzająca się w dziejach świata wojna stała się źródłem lęku, którego językowym odzwierciedleniem jest rejestrowane już w XVI wieku połączenie z czasownikiem obawiać się wojny; podobne znaczenie wnoszą też kolokacje z rzeczownikami, na przykład z SPXVI: trwogi wojny; z SLin: obawa, strach wojny oraz bojaźn zapalenia wojny. Postrzeganie wojny jako nieprzemijającego zagrożenia potwierdzają dodatkowo konstrukcje z SWar: widmo wojny oraz bicz wojny. Z kolei na wojnę jako element szantażu zwracają uwagę kolokacje: pogrożka (SPXVI, SLin) oraz groźba wojny (SWar), a także z połączenia z czasownikami: grozić / zagrozić wojna komu (SPXVI i źródła dla okresu późniejszego); SWar w tym kontekście notuje ponadto z kwalifikatorem staropolskie: porażać się wojna - 'straszyć, grozić' oraz konstrukcję, w której rzeczownik wojna zajmuje pozycję podmiotu: wojna grozi komu.

Liczne kolokacje z czasownikami komunikują zamiar rozpoczęcia lub wciągnięcia kogoś w wojnę, na przykład SPXVI notuje za słownikiem Mączyńskiego: na niepotrzebna wojne łowić - 'szukać zwady', a oprócz tego szukać wojny; KSXVII: implikować w wojnę kogo (por. implikować - 'wciągać, wmieszać zaangażować,' SWar, t. 2: 85), wprawić w wojnę kogo (por. wprawić - 'wplątać, wmotać, wpleść, SLin, t. 6: 397), determinować kogo na wojne (por. determinować kogo do czego - 'skłaniać kogo', SWar, t. 1:450), przywieść kogo do wojny (por. przywieść do czego - 'nakłonić, zachęcić, zobowiązać, SPXVI, t. 34: 275); SLin i SWar: wplątać kogo w wojnę; SWar: wciagna kogo $w$ wojnę, implikować kogo $w$ wojne, a także prowokować / sprowokować wojne oraz z formą gerundialną prowokowanie wojny. Na marginesie warto nadmienić, że w SPXVI frekwencja leksemu prowokować wynosi zaledwie jeden.

Rozpoczęcie działań wojennych poprzedza zazwyczaj okres planów i przygotowań, a samo wejście w stan wojny wymaga formalnej uchwały sejmu. Do czynności tych odsyłają połączenia z czasownikami, na przykład z SPXVI: radzić wojnę I 
o wojnie, uchwalić wojnę na sejmie, przemyślać, myślić, napocząć, ułożyć komu, narzadzić - 'przygotować, spowodować, gotować przeciwko komu, sprawować wojne (por. sprawować - 'przyrządzać, nagotować, przygotować, SLin, t. 5: 404); KSXVII: kuć (por. kuć, ob. knuć, knować - 'układać, planować, SPXVI, t. 11: 83), umyślić, zacząć, zalecać, sprawować, zrobić (nowa) wojnę, discurować o wojnie, uradzić poparcie wojny, pozwolić, gotować się na wojnę; SLin: wojnę przed się wziąć, narządzić 'nagotować, przygotować, sporządzić / sporządzać, gotować wojne przeciw komu, stroić wojny - 'nagotować, szykować', a także wojna postanowiona urzędownie od najwyższych władz; SWar: radzić o wojnie, gotować się na wojnę / do wojny, przyszykować się do wojny. W tym kontekście godne uwagi wydają się jeszcze połączenia zarejestrowane w KSXVII: uciec się / uciekać się do wojny, które wnoszą informację o podjęciu działań wojennych w ostateczności. Bliskie semantycznie jest też pochodzące ze SLin sięgać się do wojny - 'chwytać się. Z kolei połączenie odwłoczyć wojnę (KSXVII) stwierdza przesunięcie wojny na czas późniejszy, niż pierwotnie planowano. Językowym odzwierciedleniem zwyczaju rozpoczynania wojny na wiosnę jest natomiast połączenie z SLin: odwlec wojny aż po przezimie (przezim / przezima 'przezimowanie, przetrwanie zimy') oraz z KSXVII: groża wojna na wiosnę.

Słowniki rejestrują także kolokacje dokumentujące działania, których celem było niedopuszczenie do rozpoczęcia wojny; na przykład SPXVI: odwieść, hamować od podniesienia wojny, zabieżać wojnie, również z formą gerundialną zabieżenie niepokojowi a wojnie; KSXVII: ujść (por. ujść czego - 'uchronić się, uniknąć czego', SLind, t. 6: 114), zabieżeć wojny, uchronić, zatrzymać wojska od wojny oraz z formami gerundialnymi strzeżenie się, uchronienie się wojny; SLin: rozwieść wojnę - 'wyperswadować, odradzić, wybijać z myśli', oraz z rzeczownikiem odproszenie wojny (odprosić od czego - 'prośbą cofnąć, uwolnić od czego'); SWar: zajednać - 'załagodzić, zażegnać wojnę - 'zapobiec, odwrócić, oddalić, zachować od wojny, obronić od wojny - 'ustrzec, wybawić. Na wszystkie czynniki powściągające, wstrzymujące wojnę uwagę kieruje pochodzące z SWar połączenie z rzeczownikiem hamulec wojny. Godne odnotowania wydaje się jeszcze wyrażenie niewywoływanie wojny (SWar), a także konstrukcje z czasownikami, przykładowo z SPXVI: nie zadawać wojen komu, nie kwapić się na wojnę / do wojny - 'nie spieszyć się’; KSXVII: wzdrygać się wojny (por. wzdrygać się — 'wzbraniać się, SWar, t. 7: 1132).

Z przygotowaniami do wojny związane były połączenia z rzeczownikami, na przykład z SPXVI: opatrzność przy wojnie - 'roztropne, zapobiegliwe myślenie i działanie', a także potrzeba wojny, kolokacja będąca generalizacją, a przez to występująca w różnych, bardzo ogólnych znaczeniach, tu: 1. 'sprawa do załatwienia', 2. 'to, że wojna wymaga określonego działania do osiągnięcia celu'. W polu przygotowań do wojny notowane są też kolokacje z czasownikami, na przykład z SPXVI: patrzyć wojny - 'zajmować się wojną, realizować wojnę', od wojny opatrywać zamki - 'umacniać, zabezpieczać zamki na czas wojny’; KSXVII: przygotowania do wojny czynić, fabrykować wojnę (por. fabrykować - 'robić co, składać co, osobliwie co niedobrego', SLin, t. 1: 636), opatrzyć wojnę, obrócić wszystkie sity na wojnę. Odmienne znaczenie 
wnoszą natomiast połączenia pochodzące z SPXVI: omieszkać wojny - 'nie dopilnować, zaniechać, nie mieć oka na przyszłe wojny, a także nie pytać o wojnę, które odzwierciedla sposób działania bez pozwolenia czy bez zastanowienia, lecz może także być wyrazem braku zainteresowania wojną.

W odniesieniu do finansowania wojny w wieku XVI i kolejnych dużą frekwencją wyróżniał się stały związek frazeologiczny nerwy wojny ${ }^{3}$ - 'pieniądze przeznaczone na wojnę, który jest kalką z łac. nervi belli. Spośród kolokacji związanych z tym polem semantycznym na uwagę zasługują natomiast rejestrowane w SPXVI połączenia: moc wojny, które słownik objaśnia z użyciem wspomnianego frazeologizmu 'siła napędowa wojny, czyli nervus belli', a także wspomniane wcześniej polisemiczne konstrukcje potrzeba / potrzeby wojny, tu w znaczeniu 'to, że na wojnę trzeba przeznaczyć i wydać pieniądze, zaplanowany wydatek, przewidziane uposażenie’. SWar podaje nadto podatek na wojnę. Tymczasem KSXVII przynosi połączenia z czasownikami: łożyć na wojnę, krzepić wojne pieniędzmi, zaś SLin i SWar: wyszafować pieniądze na wojne - 'wydać, wyczerpać, wymarnować.

Z kolei na określenie sprzętu i wszelkich przedmiotów potrzebnych do prowadzenia wojny SPXVI rejestruje połączenia z przywoływanym już dwukrotnie rzeczownikiem potrzeba: potrzeby do wojny (należace) / około wojny / na wojnę; oprócz tego w analizowanym kontekście funkcjonowały kolokacje: rzeczy do wojny potrzebne / do wojny należace 4 . Do zabezpieczenia i środków ostrożności odnosiły się natomiast kolokacje przestrogi do wojny potrzebne (SPXVI) oraz opatrunek na wojne - 'zabezpieczenie' (SWar za słownikiem Trotza).

Kolokacje informujące o ośrodkach zarządzania lub dowodzenia wojną są nieliczne; SPXVI podaje: pierwsze miejsce w rozkazowaniu na wojnie, hetmańskie miejsce na wojnie; KSXVII: wódz wojny; SLin: naczelnictwo na wojnie - 'najwyższa komenda', zawiadacz wojny oraz połączenie z czasownikiem hetmanić na wojnie - 'dowodzić. SWar rejestruje już kolokacje nazywające instytucje charakterystyczne dla nowoczesnych struktur państwa: ministerium wojny, minister wojny, komisja rzadowa wojny, ale obok nich też przywojca i regimentarz na każda wojne, przewodnictwo / przywództwo na wojnie, zawiadacz wojny - 'dowódca, naczelnik, wódz naczelny' oraz naczelstwo na wojnie - 'najwyższa komenda', ilustrujące wpływ języka zaborcy.

Z kolei w polu semantycznym przygotowań do wojny wypada odnotować kolokacje pochodzące z SPXVI: wyprawa na wojnę, gotowość ku wyjechaniu i wyprawowaniu na wojnę, a także gotować się na wojnę. W całym okresie w kontekście wyprawiania się na wojnę bardzo licznie reprezentowane są połączenia z czasownikami ruchu, przykładów dostarcza już SStp: jechać, jić, wychadzać na wojnę; SPXVI z kolei podaje: iść, pość, jeździć, jechać, pojechać, zajechać, ruszyć się, puścić się, gonić chciwie na wojnę, a także z formą gerundialną jechanie na wojnę; KSXVII: płynąć na wojnę;

${ }^{3}$ Interesujący związek frazeologiczny cięciwa wojny - 'pieniądze' rejestruje także SWar.

${ }^{4}$ Konkretyzacją tych potrzeb czy rzeczy są bardzo liczne kolokacje z przymiotnikiem wojenny, których analiza wykracza poza przyjęte ramy niniejszego artykułu. 
SWar: chodzić, wysunąć na wojne - przenośnie 'wylec, wyroić się, wyjść tłumnie', wyjechać do wojny. Warto zauważyć, że notowane już w SPXVI kolokacje z czasownikami ciagnąć / pociągnąć na wojnę, zarówno z formą gerundialną ciągnienie na wojnę, jak i z imiesłowem przymiotnikowym ciagnacy na wojnę, zawsze oznaczały gromadne wyruszenie w drogę i odnosiły się przede wszystkim do wojska.

W zebranym materiale poświadczone zostały też połączenia z czasownikami odzwierciedlające sytuację wyprawiania na wojnę innej osoby; przykłady z SPXVI: $w y$ prawować, słać, posłać kogo, wieść kogo (na przykład wielka wielość ludzi) na wojnę; KSXVII: wyprawić, posłać kogo na wojnę; SWar: ze swego wacka wyprawić kogo na wojne - 'wyprawić kogo na wojnę własnym sumptem'. Repertuar połączeń odnoszących się do powrotu z wojny jest mniej różnorodny, najstarszą konstrukcję notuje już SStp: idący $z$ wojny (Gydączy sz voyny... sobie strawy... nye maya bracz); KSXVII i SWar podają: wrócić, powrócić z wojny, a KSXVII: szczęśliwy powrót z wojny.

Osobną liczną grupę tworzą kolokacje wskazujące na oficjalny charakter wojny. Jej rozpoczęcie, zwyczajowo regulowane w prawie międzynarodowym, powinno zostać poprzedzone formalnym aktem, w którym jedna ze stron zawiadamia drugą o wejściu w stan wojny. Odzwierciedleniem tego aktu są połączenia z rzeczownikami odczasownikowymi; w SPXVI: oznajmienie wojny - 'zapowiedź'; w KSXVII i źródłach późniejszych: wypowiedzenie wojny; w SLin: deklaracja wojny. W omawianym kontekście znacznie liczniej reprezentowane są połączenia z czasownikami nazywającymi aktywność werbalną człowieka, co pokazują przykłady: z SPXVI: wojnę opowiedzieć, odpowiedzieć, oznajmić komu czym (na przykład listy zwyczajnymi); KSXVII: wojnę opowiedzieć, wypowiedzieć / wypowiadać, deklarować; SLin: wojne przypowiedzieć; SWil: wojne wypowiedzieć; SWar za słownikiem Trotza: wojne zapowiedzieć - 'wypowiedzieć, a nadto: wojne proklamować, odpowiedzieć, przypowiedzieć - 'zapowiedzieć, oznajmić. Godne odnotowania w tym kontekście wydaje się jeszcze pochodzące ze SLin i powtórzone w SWar połączenie wojna kogo obesłać 'wypowiedzieć komu wojnę przez posła'.

$\mathrm{Na}$ akt wypowiedzenia wojny wskazują również połączenia z przymiotnikami (w istocie są to zadiektywizowane imiesłowy bierne), z SPXVI: wojna opowiedziana - 'wypowiedziana', sporadycznie podniesiona; przymiotniki te rozwijane bywają przysłówkiem przystojnie - 'zgodnie z przepisami, nakazami, głównie religijnymi, nabożnie’. KSXVII przynosi połączenie wojna deklarowana (por. deklarowany 'ogłoszony z mocą prawną', SPXVI, t. 4: 575), której przeciwstawiana jest wojna nieodpowiedna (por. nieodpowiedny - 'nieoczekiwany, nagły, którego nic nie zapowiadało', SPXVI, t. 17: 438) oraz notowane w wielu słownikach połączenie z wyrażeniem przyimkowym wojna bez wici - 'wojna nagła, bez wypowiedzenia'.

Z kolei z ogłaszaniem i rozpowszechnianiem wiadomości o wojnie łączyć należy kolokacje z czasownikami, na przykład z SPXVI: objawić - 'uczynić jawnym, oznajmić, ogłosić', ogłosić wojnę; KSXVII: obwołać wojnę (por. obwołać - 'podać do publicznej wiadomości', często o faktach lub postanowieniach nowo zaistniałych, które z chwilą ogłoszenia stają się obowiązujące; proclamare, SPXVI, t. 19: 486). 
W kontekście tym zauważyć należy jeszcze zanotowane w SLin połączenie z rzeczownikiem hasło wojny - 'ogłoszenie wojny'.

Zbiór połączeń z czasownikami odnoszącymi się do rozpoczęcia wojny jest nadzwyczaj bogaty. Liczna grupa, w której najczęściej spotykamy czasowniki dokonane, zdecydowanie rzadziej niedokonane oraz formy gerundialne, odsyła do momentu wejścia w stan wojny jako punktu na osi czasu. W tej grupie z SPXVI pochodzą następujące przykłady: wojnę począć / napocząć, wszczynać, podnieść - 'uczynić, wszcząć, podnosić / podnaszać, wznosić, ruszyć przeciwko komu oraz formy gerundialne poczęcie, podniesienie wojny; KSXVII i SLin: rozpoczynać / rozpoczać wojne z kim; SLin: wydać wojnę; SWil: wojne podnosić / podnieść; SWar: wojnę ruszyć — 'rozpocząć', podnieść, rozpocząć, wszczać / wszczynać, wytoczyć komu - 'wypowiedzieć, wszcząć, podjąć.

$\mathrm{Na}$ działania człowieka skutkujące rozpoczęciem wojny, oprócz przytoczonych, wskazują jeszcze inne kolokacje z czasownikami, na przykład z SPXVI: wojne pobudzać - 'wywoływać, narzadzić - 'spowodować, sprawować (por. sprawować 'wywołać, spowodować, sprowadzić', SWar, t. 6: 345), na wojnę postępować - 'przystępować do wykonania czegoś, oborzać się wojna na kogo - 'występować przeciw komuś, atakować', wdać się $w$ wojnę (por. wdać się $w$ co - 'wmieszać się, wplątać się, SLin, t. 6: 242); KSXVII: wdawać się w wojnę, wkroczyć w wojne, porwać się (por. porwać się - 'podjąć się czegoś, wziąć się, zabrać się do czegoś, SPXVI, t. 27: 405), rzucić się do wojny, wojne sprowadzić; SLin: poruszyć wojnę, następować wojna na kogo; SLin i SWar: wywołać wojnę; SWar: zawziąć się wojny - 'podjąć się, zabrać się na dobre, zagiąć parol', przenośnie wytrąbić wojne.

Wiele zarejestrowanych połączeń odnoszących się do rozpoczęcia wojny jest wynikiem jej skojarzenia $\mathrm{z}$ ogniem, co ilustrują na przykład zarejestrowane w SLin i SWar połączenia z czasownikami: wzniecić / wzniecać wojnę; w SWil: z gerundium rozniecanie wojny; w KSXVII: z rzeczownikiem zapał wojny (por. zapał - 'zapalanie', SLin, t. 6: 839). Taki sposób obrazowania szczególnie częsty jest w kolokacjach, w których wojna występuje jako agens, na przykład z KSXVII i SLin: wojna gorzała; SLin: wojna wżarzyła się, zakurzyła się; SWar: wojna okopciła państwo, wspłonęła, wzarzyła się - 'powstała nagle i gwałtownie, rozpaliła się, rozgorzała, zakurzyła się - 'zapaliła się ogniem, zatliła się, zakopciła się, zapaliła się. Nierzadko pojawia się on również w kolokacjach odnoszących się do dalszego przebiegu wojny, a w szczególności do jej okresu schyłkowego i zakończenia, co ilustrują kolokacje z SPXVI i SWar: podsycić / podsycać, przydusić, zgasić wojnę oraz z SPXVI: wygasić wojnę. Metaforę ognia wprowadzają niekiedy także połączenia z rzeczownikami; przykłady z SPXVI i SWar: pochodnia wojny; KSXVII i SWar: ogień, ognisko wojny; SWar: płomień, pożar wojny. Z kolei na podobieństwo wojny i burzy zwracają uwagę pochodzące z SPXVI połączenia z rzeczownikiem: borza wojny oraz z czasownikiem: wojna wzburzyła się od kogo; z SLin: obórzać się wojna na kogo. Na marginesie warto dodać, że obecny w polszczyźnie XVI wieku obok rzeczownika burza / borza wyraz burzka funkcjonował jako jeden z licznych synonimów leksemu wojna (por. SPXVI, t. 2: 516). 
Liczne połączenia z czasownikami, wśród których nierzadkie są czasowniki ruchu, odzwierciedlają dynamiczny charakter wojny. Spośród najbardziej charakterystycznych kolokacji warto wymienić przykłady, w których wojna występuje jako agens, na przykład z SPXVI: wojna przyszła, podniosła się, powstała, sstała się na niebie, rostnie - 'ma początek, powstaje, tworzy się,' urosła, wiedzie się, toczy się; KSXVII: wojna nastała; SLin: wojna się toczy, wrzała; SWar: wojna natoczył się, obaliła się na Polskę, padła, przypadła, zawzięła się, $z$ nagła zaczęła się. Dynamiczny charakter wojny poświadcza również kolokacja z rzeczownikiem wir wojny (SWar). Z kolei połączenia: wojna gruchnęła, wojny brzmia (KSXVII), wojna wybuchła (SWar) są odzwierciedleniem akustycznej strony konfliktu. Na percypowanie wojny zmysłem słuchu wskazują ponadto kolokacje: huknąć wojną, otrąbić wojny (KSXVI). W grupie tej spotykane są także połączenia z rzeczownikami, na przykład z SPXVI: brzęk / brzęki wojny - 'dźwięki, szczęk wojny', głos wojny, okrzyk na wojnę; KSXVII: odgłos wojny, wrzawa wojen, trąby na wojny; SWar z kolei notuje głos wojny, któremu można przeciwstawić połączenie cisza po wojnie, czyli pokój.

Bogato udokumentowany zbiór połączeń z czasownikami służy nazywaniu różnych form aktywności podejmowanych przez człowieka w związku z toczącą się już wojną, na przykład SPXVI za słownikiem Mączyńskiego podaje: potrwać w wojnie 'pozostać jakiś czas bez zmiany w jakiejś sytuacji lub w jakimś stanie', a nadto notuje: wojne wieść, zwodzić z kim (por. zwodzić - 'stoczyć,' SWar, t. 8: 651), toczyć / stoczyć / staczać z kim, prowadzić, odprawiać / odprawować - 'brać udział w wojnie', podołać wojnie - 'sprostać wojnie', dzierżeć - 'wykonywać, spełniać, sprawować czynności', czynić wojne - 'sprawować, przeprowadzać, prowadzić, wytrwać (por. wytrwać 'oprzeć się, nie ulec, dotrzymać placu', SWar, t. 7: 1085), zabawić się wojna, na wojnie drzeć jeden drugiego; z kolei mieć / miewać wojnę od kogo w ujęciu czynnym może oznaczać 'brać udział w wojnie', w ujęciu biernym zaś 'być napadanym', czyli być bezpośrednim biernym obiektem zewnętrznego działania. KSXVII przynosi: odprawować / odprawić wojny; SLin: wojne wieść, toczyć / stoczyć, kołatać się wojnq - 'wzajemnie się niepokoić, sobie dokuczać; SWil i SWar: wojnę z kim prowadzić, SWar: wojować wojnę, a poza tym: wojnę wieść, toczyć, wojna następować na kogo, turbować kogo - 'kłopotać, niepokoić, martwić, wojny przewalczyć - 'walcząc odbyć albo odprawić, przewlekać, stroić - 'staczać, prowadzić, wieść, zawziąć się wojny - 'podjąć się, zabrać się na dobre, zagiąć parol.

Zabiegi zwiększające zasięg oraz intensywność działań wojennych odzwierciedlają pochodzące z SPXVI połączenia z czasownikami: nasiać, płużyć wojny - 'szerzyć oraz pobudzać wojny - 'wzmagać wojny'. Z kolei o mobilizowaniu uczestników konfliktu do podjęcia lub zintensyfikowania działań informują połączenia z SPXVI i KSXVII: pobudzić do wojny; z KSXVII: animować kogo na wojne - 'zagrzewać, dodawać serca'; z SLin i SWil: potrębować na wojnę - 'pobudzać, wzywać na wojnę'; z SLin: wołać na wojnę; z SWar: zatrąbić na wojne - 'pobudzić', a obok tego 'dać hasło na wojnę'. 
Zmienne koleje wojny wyrażają połączenia z rzeczownikami: wojny progres oraz regres na wojnie (KSXVII). Działania będące reakcją na zmieniające się natężenie wojny w całym okresie komunikują kolokacje z czasownikami podsycić / podsycać (SPXVI, SWar), podczas gdy w SWar pojawia się także konstrukcja budzić wojnę. Znaczenie przeciwne łączy się natomiast z czasownikami przydusić (SPXVI) oraz gasić wojnę (SWar). Z kolei z sytuacją ponawiania wcześniej zawieszonych lub zakończonych działań wojennych wiążą się czasowniki: wznawiać, wskrzesić (SLin) czy odnowić wojnę (SLin, SWar). Z SLin pochodzą jeszcze połączenia, w których wojna zajmuje pozycję podmiotu: wojna odmłodła, odnowiła się, odżyła. Zarejestrowane w KSXVII połączenie odnawiać wojnę ludem świeżym informuje natomiast o wzmocnieniu wojny posiłkami, z kolei SPXVI w znaczeniu 'wsparcie, wspomożenie, ratunek' notuje kolokację pomoc na wojnę.

Liczne połączenia z czasownikami informują o zakończeniu wojny, na przykład z SPXVI: poprzestać wojny - 'odstąpić, zaniechać, obrocić wojnę w pokój, dać pokój wojnie, wygasić, skazować wojne - 'rozstrzygnąć' (por. skazać / skazować - 'dekret wydać, wyrok uczynić, wyroczyć,' SLin, t. 5: 279); KSXVII: znosić wojny przez pokój, uczynić koniec wojnie, dać pokój wojnie, poniechać wojny, wywikłać się z wojny 'rozpocząć rokowania', rozjąć wojne - 'rozjednać, rozsądzić, rozstrzygnąc', skończyć wojnę, kończyć wojne przez traktaty, a także wojna traktatami się skończyła; SLin: zajednać, rozja wojnę, odjać się - 'uwolnić się z czego, pozbyć się czego', poniechać, zaniechać wojny, poprzestać od wojny, uczynić koniec wojnie. Notowane są też połączenia, w których wojna występuje w funkcji podmiotu: wojny ustaną (SPXVI), wojna skończyła się (SLin), wojna się dotoczyła (SWar). Informację o zakończeniu konfliktu wnosi również pochodząca SLin kolokacja z przymiotnikiem wojna porównana (por. porównać - 'pomiarkować, pogodzić). Z kolei połączenie zawiesić wojne (SLin i SWar) zawiadamia nie o zakończeniu, lecz o wstrzymaniu działań wojennych na określony czas. W tym kontekście godna uwagi wydaje się jeszcze pochodząca z SWar kolokacja z przymiotnikiem wojna gabinetowa, oznaczająca rokowania.

Rozstrzygnięcie wojny opisują zarówno kolokacje z rzeczownikami, na przykład z SPXVI: $w$ wojnie zwycięstwo i przegranie, wygranie wojny, jak i z czasownikami, przykładowo z SPXVI: przegrać wojnę czy z KSXVII: wygrać wojnę, a także powiodła się wojna lub wojna wzięła skutek. Z kolei połączenia z SPXVI: poszczęściło się na wojnie, z SPXVII: źle się powiodło na wojnie, z SLin: poszańcowało się komu na wojnie - 'poszczęściło się komu' mogą odnosić się zarówno do przejściowych, jak i ostatecznych wyników toczącego się konfliktu. W tym kontekście warte odnotowania wydaje się jeszcze połączenie ustępować komu placu na wojnie (SLin).

W polu semantycznym związanym z realizacją celów i planów wojennych dominują konstrukcje z czasownikami, w których rzeczownik wojna odgrywa rolę dopełnienia wyrażonego narzędnikiem (zob. na ten temat Pisarkowa 1984: 106), na przykład z SPXVI: wojna dochodzić czego, odiskać - 'odzyskać, odzyskiwać co, dostać czego, odpierać, sprawić co, rozstrzygnąć co, znędzić kogo, uganiać rozbójstwa nieprzyjacielskie - 'napady rabunkowe', zhołdować kogo i do postuszeństwa przywieść, zetrzeć, 
zgubić, znędzić kogo; KSXVII: wojna uspokoić kogo, zakłócić co, dokuczać komu, wojnami dostać co, obrocić w niwecz co; SLin: wojna wytracić kogo, pożyć kogo — 'dać mu radę, pokonać go, zabić, porażać kogo — 'pobić, uderzyć, zwalić, konać kogo 'zupełnie go znieść, zniszczyć, zgładzić', ponękiwać kogo - 'pokonać, powalić, zwyciężyć kogo, podbić co, kogo, przechłościć kogo, dochodzić czego; SWar: wojna dokonać kogo - 'pokonać, zgnębić do reszty', dochodzić czego. Konstrukcje z czasownikami realizujące inny schemat składniowy notowane są rzadziej, na przykład z SPXVI: obigrać - przenośnie 'pokonać, zwyciężyć, pobić kogo na wojnie, podhołdować sobie kogo prawem wojny; KSXVII: na wojnie odjać co komu, przez wojne poskromić kogo, dostać przez wojne co; SWar: wygubić, ubić, pogromić kogo na wojnie; wreszcie SLin: wojna odjęła co komu. W tym kontekście sporadycznie występują również połączenia z imiesłowami biernymi, na przykład SPXVI notuje: wojną odbierany, przyłaczony walką a wojną, a SLin: zawojowany przez wojnę.

Językowym odzwierciedleniem strat powodowanych przez wojny stało się połączenie z rzeczownikiem szkody na wojnie (SPXVI), podczas gdy ślady wojny (SWar) zwracają uwagę na trwałe skutki. W tym polu semantycznym warto wymienić kolokacje z KSXVII: miasta zniesione przez wojny, znędzony kraj po wojnie; z SLin: wojnami wyniszczony, wojna nadkołatany - 'trochę wzruszony, nadwerężony', wojna utrektany i porażony, a ponadto wykazujące się niewielką frekwencją połączenia z SWar: ekswiscerujaccy się wojna z kim (łac. exviscerare - 'wyczerpywać siły, wycieńczać') i wyekswiscerowany wojna / przez wojnę z kim. O następstwach wojny informują także konstrukcje z czasownikami, na przykład z SPXVI: wojna dostać się pod moc kogo, na wojnie zgubić co; KSXVII: stracić co przez wojne, wojna wojska strudzić, podczas wojny siła ludzi ubyło; SLin: wojna się lud nadszarzał (por. nadszarzać się - 'szarzeniem nadwątlić, nadtyrać'); SWar: wykruszyć siły w wojnie. Godne uwagi są również połączenia, w których rzeczownik wojna przyjmuje pozycję podmiotu, na przykład z SPXVI: wojna zgubi Rzeczpospolita, wojna ciagnie za sobq w upadek ku zginieniu, wojna przynosi w majętności szkodę i krwie ludzkiej przelanie, wojna przeszkodziła co; KSXVII: wojny umniejszyły ludu, wojny dokuczaja komu, wojny pożary wzbudzaja. Konsekwencje wojen opisują też odnotowane w SLin połączenia z przymiotnikami złożonymi: wojna płaczorodna - 'przyczynę łzom dająca', wojna rodzicobójna - 'zabijająca rodziców’ oraz wojna ludobójcza; SWar natomiast notuje już kolokację wojna eksterminacyjna. Jednym ze skutków wojny była niewola, co dokumentują połączenia z KSXVII: pojmaniec na wojnie, nieprzyjaciel na wojnie wzięty, żołnierze wzięci na wojnie, więźniowie pojmani pod wojnę oraz z SLin: jęty, pojmany na wojnie — 'jeniec'.

Wojnie towarzyszą działania bezprawne, staje się ona okazją do grabieży i zdobywania łupów, co poświadczają połączenia z czasownikami, z których najstarsze zarejestrowane zostało w SStp: na wojnie nabył co - 'zdobył' (iako Laurenciusz rzeczy tich ne podkradl..., ale gich oth neprzyaczol na woyne nabyl - 1411 rok); powtarza je SPXVI, podobnie jak KSXVII: nabyć mieczem na wojnie, obłowić się na wojnie, skarby najdować na wojnach, a także zbogacić się pod pretekstem wojny. Ze 
SWar z kolei pochodzą dwa połączenia o przeciwstawnym znaczeniu: wojna bogaci kogo oraz wojna uboży kogo. W tym kontekście godne uwagi są także połączenia z rzeczownikami: skarby $z$ wojen (KSXVII), zdobycz na wojnie (SLin) oraz kolokacja z przymiotnikiem: wojna obłowna - 'dająca możność obłowienia się' (SWar). Jednakże udział w wojnie może też stać się okazją do różnorakich zasług i chwały, czemu dają wyraz rozmaite konstrukcje, na przykład z SPXVI: zasłużony na wojnie, cześć $i$ chwała $z$ wojny, $z$ wojny przyjść maja sława, zacność $i$ wielkie pożytki; z KSXVII: herb nadany na wojnie, na wojnie zasługa honoru szukać; z SWar: odznaczyć się na wojnie.

W grupie połączeń opisujących postawę człowieka wobec wojny należy odnotować zaczerpniętą z SPXVI kolokację z rzeczownikiem utworzonym charakterystycznym dla tego okresu sufiksem -ość (zob. Ostrowska-Mróz 1962) chciwość wojny - 'chęć wojowania'; z kolei KSXVII podaje: chęć do wojny, a SWar za słownikiem Trotza: ociętna do wojny ochota - 'zacięta, zaciekła'. W tym polu semantycznym można zauważyć także połączenia z czasownikami, co ilustrują przykłady z KSXVII: smakować sobie wojnę (por. smakować sobie co - 'upodobanie w tym mieć, polubować', SLin, t. 5: 341), karmić się i żywić wojnami, aplikować się do wojny (por. aplikować się - 'przykładać się do czego, pilnie koło czego chodzić, SWar, t. 1: 48), pospolitować się w wojny (por. pospolitować się - 'wdawać się, SWar, t. 4: 341), a także z przymiotnikami, na przykład z SLin: ochotny, skwapliwy do wojny; SWar: wojnie oddany. Skrajnie odmienną postawę odzwierciedla natomiast połączenie z rzeczownikiem: wstręt do wojny (SWar). Niechęć do wojny komunikują również kolokacje z czasownikami, na przykład z KSXVII: wojna przykrzy się komu (por. przykrzyć się - 'wzbudzać w kim niechęć, być postrzeganym jako przykry, trudny do zniesienia', SPXVI, t. 33: 394); z SLin: oprzykrzyć wojne komu — 'ohydzić, omierzić, wojna zmierzła żołnierzom. Godne uwagi wydaje się też połączenie pochodzące ze słownika Mączyńskiego, a zarejestrowane zarówno w SLin, jak i w SWar: wstążyć się na wojnie - 'sprzykrzyć sobie wojnę. W podobnym kontekście SLin podaje jeszcze: trwożyć soba / trwożyć się $w$ wojnach - 'smęcić się, smucić.

Grupa kolokacji odzwierciedlających relacje człowiek-wojna jest niezwykle bogata i wewnętrznie zróżnicowana. Udział w bezpośrednich działaniach wojennych, a szczególnie okres początkowy, postrzegany jest jako doświadczenie wielkiej wagi, co potwierdzają pochodzące z SWar połączenia z rzeczownikiem: chrzest na wojnie oraz z czasownikiem: doświadczyć wojny. Z początkowym czasem służby wiązać należy ponadto kolokacje: pokosztować wojny (SPXVI) oraz spróbować wojny (SWar). Z kolei dokonujące się pod wpływem wojny zmiany w człowieku odzwierciedla połączenie: hartować się na wojnie (SWar). Informowaniu o śmierci służą konstrukcje z czasownikami, przykładowo z SPXVI: poginać, polec, być wygładzonym od kogo; KSXVII: zginąć na wojnie. Połączenia zginąć na wojnie / w wojnie rozwijane bywają przysłówkiem chwalebnie (KSXVII) lub żałośnie (SPXVI). Na szczególną uwagę zasługuje konstrukcja na wojnie gardła nieść / nosić dla kogo, które SPXVI objaśnia jako 'ofiarować swe życie za kogo’. 
Związane z udziałem w wojnie zagrożenie i trud potwierdzają połączenia z czasownikami, na przykład z SPXVI: na wojnę zdrowie nieść za kogo; SWar: wytyrać się na wojnach. Z kolei udrękę wojny opisują różnorodne konstrukcje z SPXVI: na wojnie cierpieć nędzę, okrucieństwo na wojnie, wygłodzony na wojnie; z KSXVII i SLin: skaleczony na wojnie - 'raniony'; z SWar: raniony na wojnie. Nie brak w tej grupie połączeń, w których rzeczownik wojna zajmuje pozycję podmiotu: wojna wyciska łzy, nie litowała kogo - 'nie oszczędzała, nie ochraniała' (SWar). Natomiast wpływ wojny na kształtowanie się ludzkich postaw i zachowań ukazują połączenia z KSXVII: wojna czyni ludzie okrutne, strudzone i skaleczone na wojnach życie oraz z SWar: zbrutalizowany przez wojnę. W SWar odnotowano także kolokację potwierdzającą konieczność regeneracji i odpoczynku po zakończeniu wojny: wyspoczywać po wojnie - 'spoczywając wydobrzeć, wypocząć.

Kolejne, ostatnie już grupy kolokacji koncentrować się będą wokół tematów związanych $\mathrm{z}$ wojskowością, ponieważ $\mathrm{w}$ przeszłości jednym ze znaczeń analizowanego leksemu było 'wojsko'. Sytuację formowania wojska komunikowały połączenia z rzeczownikami odczasownikowymi, na przykład z SPXVI: pobór na wojnę; KSXVII: zaciag na wojnę / wojny, jak również z czasownikami dokonanymi, rzadziej niedokonanymi, na przykład z SPXVI: na wojnę się popisać - 'wpisać się do ewidencji'; KSXVII: zaciagnać się / zaciagać się na wojnę / $w$ wojnę. SWar $\mathrm{w}$ tym kontekście odnotowuje kolokację $\mathrm{z}$ przymiotnikiem: nawerbowani na wojnę. $\mathrm{Z}$ kolei pochodzące z SPXVI połączenia z rzeczownikami: ruszenie szlachty na wojnę czy pospolite ruszenie na wojnę, a także połączenie $\mathrm{z}$ czasownikiem z SLin: zbierać ludzi na wojne odnosiły się raczej do bezpośrednich działań związanych z przygotowywaną wyprawą wojenną.

Wybrane z SPXVI połączenia z rzeczownikami odczasownikowymi: stużenie wojny oraz powinność służenia wojny zwracają uwagę na prawną naturę obowiązku. Słownik rejestruje również kolokację komunikującą znaczenie przeciwne: niesłużenie wojny (rzeczownik od nie służyć - 'nie wypełnić obowiązku służby wojskowej'). Dawne uregulowania prawne i zwyczaje znalazły językowe odzwierciedlenie w połączeniach z SPXVI: służyć wojne przez się osobami swemi oraz służyć wojne przez kogo inszego. Do pełnienia służby wojskowej zobowiązane były osoby w określonym wieku, co przekazują następujące kolokacje z SPXVI: doróść wojny - 'być zdolnym do walki'; z KSXVII: od wojny wiek wolnym czyni; z SWar: dla podeszłych lat na wojnę iść nie można. Godne odnotowania wydaje się też połączenie z SPXVI: odejść dla wojny, będące odbiciem sytuacji porzucenia służby lub miejsca pańszczyźnianego przypisania do ziemi na rzecz służby wojennej.

W całym analizowanym okresie rejestrowane są pojedyncze kolokacje z czasownikami, odzwierciedlające tendencję do unikania służby w wojsku. Najstarsze świadectwo przynosi już SStp: wybawić od wojny (iaco ma mal Mscignew s woyni wibawicz y o tho str[z] aczi mego gimena sa trzy grziwni - 1398 rok). Z kolei zaczerpnięta z SPXVI konstrukcja nie wypuścić kogo $z$ wojny informuje o niechęci do zwalniania $\mathrm{z}$ obowiązku służby wojskowej. Z SLin pochodzi natomiast połączenie chronić 
się wojny - 'unikać służby w wojsku, na wojnie', a z KSXVII: uciec $z$ wojny, czyli samowolnie oddalić się i porzucić służbę. W tym kontekście godne uwagi wydają się jeszcze połączenia z SPXVI, które mogły odnosić się zarówno do służby w wojsku, jak i samej wojny: opuszczać wojnę — 'zaniedbywać, nie kwapić się na wojnę / do wojny oraz odrywać kogo od wojny - 'sprawić, żeby ktoś przestał zajmować się wojną?.

Wśród kolokacji związanych semantycznie z przygotowaniem wojska do wojny należy zauważyć pochodzące ze SPXVI połączenie cień wojny, oznaczające ćwiczenie wojenne (por. cień - 'namiastka, próba'). Słownik rejestruje również połączenie z czasownikiem: naćwiczyć się w cieniach wojny. Z kolei na wojnę okazanie oznaczało stawianie się na przegląd gotowości bojowej. Z okresem szkolenia żołnierzy łączyły się również kolokacje z czasownikami, SPXVI podaje: nauczać wojny / do wojny; KSXVII: nauczyć się wojny, wprawić kogo w wojnę - 'wdrożyć kogo w co', wćwiczać się w wojnę oraz zaprawiać do wojny kogo.

Przydatność lub nawet biegłość w sprawach wojskowych komunikuje połączenie $\mathrm{z}$ rzeczownikiem mistrz wojny (SLin). Jednakże w tym polu semantycznym słowniki częściej rejestrują połączenia odpowiedniego czasownika z wyrażeniem przyimkowym do wojny, na wojnę, koło wojny; w SPXVI są to: godzić się do wojny / na wojne 'nadawać się, być zdatnym do służby', rozumieć koło wojny - 'znać się na wojnie, być obeznanym z wojną; w KSXVII: mieć experientia do wojny (por. eksperjencja 'doświadczenie, biegłość, SWar, t. 1: 681). Dość licznie poświadczone są nadto połączenia przymiotnika z wyrażeniem przyimkowym, przykładowo z SPXVI: godny do wojny / ku wojnie - 'mający predyspozycje, mogący oddać usługi', ochotny do wojny - 'chętny, gorliwy, pilny', gotowy do wojny - 'wyszkolony, wyposażony', ćwiczony $w$ wojnie - 'biegły w rzemiośle rycerskim, znający się na sprawach wojskowych', obrany na wojne - 'wybrany z kilku lub wielu możliwych', przebrany na woj$n e$ - 'doborowy' (por. przebrany - o wojsku 'doborowy', SPXVI, t. 31: 37). W tym kontekście na uwagę zasługuje także połączenie pochodzące z KSXVII: pospolite ruszenie ćwiczeńsze wojnami. Znaczenie przeciwstawne do przywołanych kolokacji wnosi natomiast połączenie z czasownikiem: nie umieć wojny (SPXVI).

Podsumowując dotychczasowe rozważania, należy podkreślić, że wyekscerpowane ze słowników kolokacje z rzeczownikiem wojna w pełni odzwierciedlają jego różnorodne znaczenie jako 'konfliktu', 'walki', 'wyprawy wojennej,' 'wojska' oraz 'obowiązku służby wojskowej. W całym opisywanym okresie pod względem formalnym zdecydowanie dominują połączenia z czasownikami, połączeń z rzeczownikami zarejestrowano o wiele mniej, a konstrukcje z przymiotnikami czy wyrażeniami przyimkowymi są jeszcze rzadsze.

Kolokacje czasownikowe służą przede wszystkim nazywaniu rozmaitych czynności podejmowanych przez człowieka w związku z wojną; dotyczą one zarówno planowania, przygotowywania, $w$ tym formowania, szkolenia i przemieszczania wojska, jak i samego prowadzenia działań wojennych i realizacji zamierzonych celów. Szczególnie bogaty zbiór połączeń z czasownikami dokumentuje czynności związane $\mathrm{z}$ rozpoczęciem, formalnym wypowiedzeniem wojny oraz zakończeniem 
konfliktu. Liczne połączenia z czasownikami, a szczególnie konstrukcje, w których wojna zajmuje pozycję podmiotu, doskonale odzwierciedlają dynamiczny charakter wojny (na przykład wojna wybuchła, toczy się, idzie). Wraz z połączeniami rzeczownikowymi dowodzą też metaforycznego sposobu obrazowania wojny jako żywiołu ognia lub burzy poświadczonego w całym analizowanym okresie. Konstrukcje te zdają się dowodzić, że człowiek jako sprawca wojny nie do końca sprawuje nad nią kontrolę i nie jest w stanie przewidzieć jej przebiegu oraz skutków, co potwierdzają również takie kolokacje, jak wir lub widmo wojny.

Wojna jako jeden ze sposobów realizacji kontaktów społecznych nieustająco wykorzystywana jest jako przedmiot szantażu i nacisku, czego językowym odzwierciedleniem jest na przykład połączenie grozić wojna, jednocześnie jednak staje się ona istotną przyczyną zawierania sojuszy. Niezmiennie pozostaje też źródłem lęku i przedmiotem spekulacji myślowych, co dokumentują zarówno kolokacje z czasownikami, jak i z rzeczownikami (na przykład obawiać się wojny, mniemanie woj$n y$ ). W konstrukcjach z rzeczownikami poza zupełnie wyjątkowymi połączeniami, typu wojna poddanych, wojna bogów, rzeczownik wojna zawsze występuje w funkcji członu zależnego grupy nominalnej ukonstytuowanej przez inny rzeczownik.

Wojna jako wydarzenie historyczne lokowana jest w konkretnym czasie i przestrzeni, czemu najlepiej służą połączenia z przymiotnikami. Przymiotniki opisują także inne parametry wojny, jak strategia, taktyka, dynamika przebiegu, przede wszystkim są jednak językowym odzwierciedleniem determinowanych przez wojnę emocji oraz istotnym świadectwem wartościowania wojny, nierzadko z względnej perspektywy (na przykład: wojna dobra obok wojna szkodliwa, wojna sprawiedliwa obok niesprawiedliwa). Z kolei połączenia z wyrażeniami przyimkowymi niezmiennie znajdują zastosowanie w nazywaniu stron i przyczyny konfliktu (na przykład wojna $z$ nieprzyjacioly, wojna o rzeczy słuszne). Wiele z przedstawionych dawnych połączeń z rzeczownikiem wojna odznacza się znaczną trwałością i w niezmienionej postaci występuje również we współczesnej polszczyźnie.

\section{Bibliografia}

Teksty źródłowe

KSXVII - Kartoteka „Słownika języka polskiego XVII i pierwszej połowy XVIII wieku”: http://www. rcin.org.pl/publication/20029.

SLin - Linde S. (1854-1860): Słownik języka polskiego przez M. Samuela Bogumiła Linde, t. 1-6, wyd. 2, Lwów.

SPXVI - Słownik polszczyzny XVI wieku (1966-2012): t. 1-34, red. M.R. Mayenowa, F. Pepłowski, t. 35, red. K. Mrowcewicz, P. Potoniec, Wrocław (1966-1994)-Warszawa (1995-2012).

SStp - Stownik staropolski (1953-2002): red. S. Urbańczyk, t. 1-11, Kraków.

SWar - Słownik języka polskiego (1900-1927): red. J. Karłowicz, A.A. Kryński, W. Niedźwiedzki, t. 1-8, Warszawa.

SWil - Słownik języka polskiego (1861): red. A. Zdanowicz et al., t. 1-2, Wilno. 


\section{Literatura}

Ostrowska-Mróz E. (1962): Rzeczowniki z przyrostkiem -ość w języku XVI wieku, [w:] Odrodzenie w Polsce, red. M.R. Mayenowa, Z. Klemensiewicz, t. 3. Historia języka, cz. 2, Warszawa, s. 303-503.

Markowski A. (2004): Kultura języka polskiego. Teoria. Zagadnienia leksykalne, Warszawa.

Pisarkowa K. (1984): Historia składni języka polskiego, Wrocław-Warszawa-Kraków.

Przybylska R. (2007): Z problemów słownikowego opisu łaczliwości rzeczownika, [w:] Nowe studia leksykograficzne, red. P. Żmigrodzki, R. Przybylska, Kraków, s. 69-77.

Rokicka T. (2007): Status kolokacji w „Wielkim słowniku języka polskiego”, [w:] Nowe studia leksykograficzne, red. P. Żmigrodzki, R. Przybylska, Kraków, s. 79-86.

Węgrzynek K. (2007): Związki frazeologiczne w „Wielkim słowniku języka polskiego”, [w:] Nowe studia leksykograficzne, red. P. Żmigrodzki, R. Przybylska, Kraków, s. 87-100.

\section{Collocations of the lexeme wojna ['war'] in the history of the Polish language}

\section{Summary}

The paper presents collocations of the noun wojna ('war') from the diachronic perspective. Gathered from historical dictionaries of the Polish language, the collocations amply illustrate four different meanings of the lexeme: 'conflict', 'fight,' 'military expedition' and 'army'.

In respect of grammar, the collocations with verbs decidedly predominate, adequately reflecting the dynamic nature of war and a metaphorical way of its representation as the elements of fire and storm, the manner recorded by the collocations with nouns as well. A vast repertoire of the collocations documents beginning, waging and ending of war. Various parameters of war, such as time, space, strategy, are described by the collocations with adjectives, which also linguistically reflect emotions determined by war and bear testimony to its values from a relative point of view. Many of the collocations are characterized by considerable durability, therefore they have been preserved in the contemporary language.

Keywords: lexeme wojna, collocation, semantics, linguistic worldview. 